\title{
Escultura conceptual mexica: la simbiosis águila-felino
}

Ignacio Díaz Balerdi

Universidad del País Vasco

En las páginas que siguen se analiza una obra escultórica de sobresaliente factura, que se conserva en el Museo Nacional de Antropología de México D.F. Se trata de un animal fantástico con cuerpo de ave, probablemente de águila, mientras que su cabeza parece corresponder a un felino: es decir, la yuxtaposición de dos animales emblemáticos y cuya trascendencia en el plano simbólico está fuera de toda duda. Pretendemos plantear un acercamiento en profundidad a la pieza y sentar las bases para una discusión sobre su significado. Partimos, en este intento, del convencimiento de que toda obra de arte transciende sus peculiaridades morfológico-estilísticas y se configura como elemento o eslabón lingüístico de un discurso perfectamente estructurado. Un discurso que no utiliza palabras sino que se articula a base de diseños plásticos, en este caso escultóricos, aunque -como veremos - la relación entre ambas esferas, la lingüística y la escultórica, es estrecha y permite establecer unos paralelismos fundamentales a la hora de desentrañar las claves de esta faceta de la plástica prehispánica.

En la sala mexica del Museo Nacional de Antropología de México D.F. se conserva una pieza escultórica de sobresaliente factura y no menos enriquecedoras implicaciones iconográficas (fig. 1). Se trata de un animal fantástico con cuerpo de ave, probablemente de águila, mientras que su cabeza parece corresponder a un felino: es decir, la yuxtaposición de dos animales emblemáticos y cuya trascendencia en el plano simbólico está fuera de toda duda. La figura, aunque con importantes deterioros, permite apreciar la perfección técnica y la capacidad de plasmación naturalista que alcanzaron los escultores mexicas. El cuerpo se apoya actualmente sobre el vientre, pero los deterioros visibles permiten suponer que en un principio poseía patas sobre las que sostenerse. La cabeza está erguida. Los ojos son elípticos y sus órbitas ligeramente resaltadas. La frente, redondeada, se prolonga entre los ojos formando el arranque del hocico. Tanto su parte frontal como las fauces se hallan muy deterioradas. Los belfos son lisos y, en la comisura del lado izquierdo, dejan ver tres molduras en la mandíbula de arriba, correspondientes a los molares. El cuello y la parte superior de la frente y nuca se hallan cubiertos de plumas: cuello de felino por su grosor, pero perfecta transición hacia el cuerpo de ave. Las plumas son cortas en el tercio delantero del cuerpo y largas en el resto. La parte de la cola ha des- 
aparecido. Cabe señalar además la existencia de dos elementos asociados: en la cabeza, un adorno radial que parte de una voluta en el centro; en la espalda del águila, un atributo parecido al pectoral con que habitualmente se adorna la figura de Tezcatlipoca y que consiste en un círculo del que cuelgan dos bandas, limitado arriba por dos molduras horizontales paralelas.

La obra es sencilla en cuanto a concepción, y no adolece de excesivas complicaciones en cuanto a elementos asociados que encarnen una cadena de implicaciones simbólicas progresivamente enriquecedoras. Pero esa simplicidad, desnuda y evidente, representa la más efectiva complejidad en lo que se refiere a la visión del mundo y del hombre en la sociedad mexica. No estamos ante un ejercicio de fantasía o de imaginación desbordada, sino ante la plasmación, mediante una envidiable economía de elementos, de lo que Soustelle denominaba ligazón de imágenes tradicionalmente asociadas.

El resultado, en cada una de sus partes componentes, es de gran naturalismo y acusa una concepción volumétrica muy del gusto mexica. La cabeza se trabaja a base de suaves curvaturas, sin bruscas transiciones de planos ni cortes pronunciados. Sin embargo, el plumaje del águila posibilita la preponderancia de la línea, de distinto tamaño y amplitud según lo requiera cada zona: plumas cortas y más redondeadas en el tercio delantero del cuerpo, largas y más rectas en el resto.

Como hemos dicho, probablemente la pieza se sostenía sobre las patas del ave, ya que aún quedan algunos restos de sus arranques. Tal vez podría pensarse en esto como en un tour de force en cuanto a equilibrio y contrabalanceo de pesos. No es tan descabellado afirmarlo si observamos que la cola, aunque hoy perdida en parte, debía prolongarse hasta alcanzar un tamaño parecido al de la cabeza del felino, con lo que las líneas de gravedad confluirían en el punto medio de la parte inferior del ave, posibilitando así que las patas cumplieran su función de apoyo. Para ello, además, se cuida mucho el carácter estático y la ausencia de movimiento, sin que esto implique que la obra carezca de fuerza y vivacidad.

Observando la pieza se pueden plantear en principio tres interrogantes acerca de su ubicación, su cronología y su significado. De su ubicación original nada se sabe, con lo cual se pierde una clave importante a la hora de adscribir la obra a un contexto determinado. Respecto a su cronología,

1 Soustelle, Jacques: La pensée cosmogonique des anciens mexicains. Paris, 1940, pág. 9. 
cabría suponerla bastante avanzada a tenor de la técnica con la que se trabaja: la depuración formal, que nos estaría hablando de una perfecta asimilación de los diversos modelos de los que se nutre la plástica mexica, unida a un progresivo naturalismo de los motivos animales, quizá nos permitieran ubicarla tentativamente en la cuarta y última fase propuesta por Pasztory, ${ }^{2}$ la correspondiente al gobierno de Moctezuma Xocoyotzin, que coincide con el momento de mayor esplendor y diversidad de un largo proceso de creación plástica.

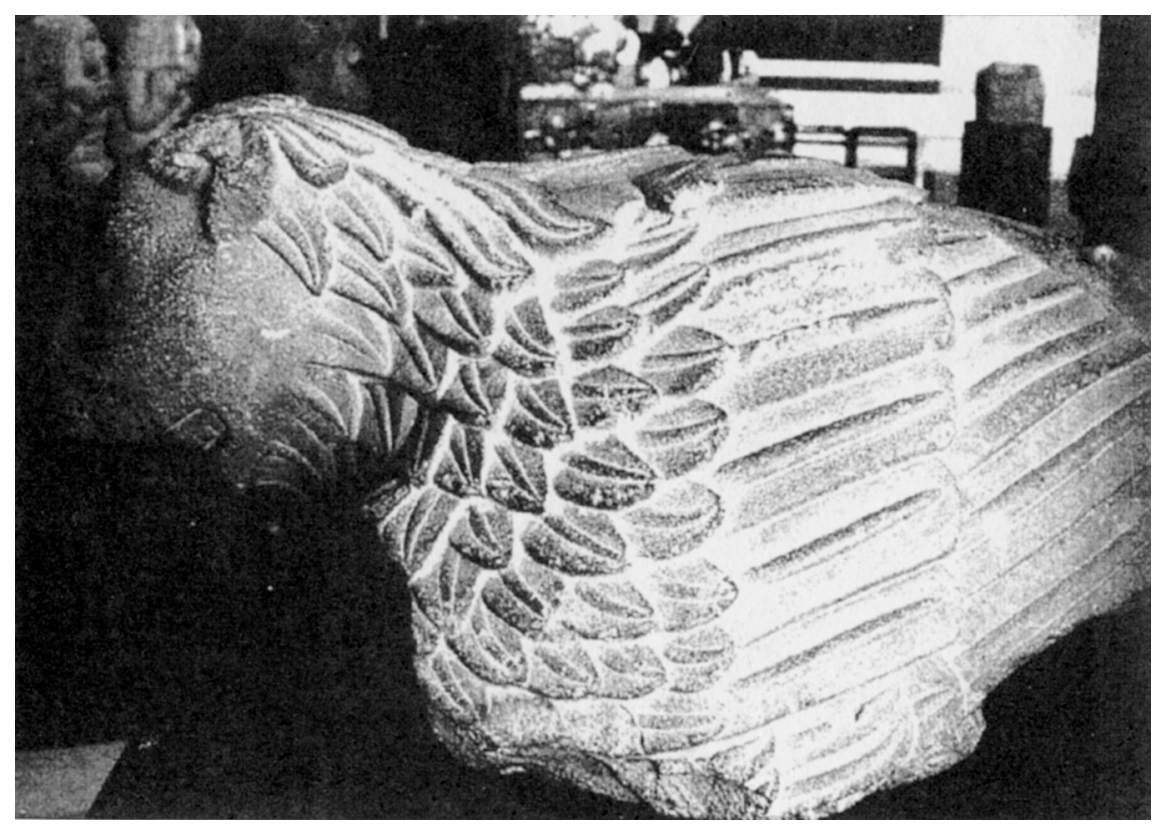

Fig. 1.-Animal fantástico con cabeza de felino y cuerpo de ave. Museo Nacional de Antropología. México D.F..

Cabe incluso, a partir de este segundo interrogante, plantearse la posibilidad de que la pieza fuera realizada ya en tiempos coloniales o, cuando menos, que no fuera estrictamente de tiempos mexicas. Y esto, que en principio puede parecer un planteamiento superfluo, cobra cierto tinte inquietante cuando constatamos que no se conocen figuras mexicas parecidas y

2 Pasztory, Esther: Aztec Art. New York, 1983, pág. 143. 
que las fuentes del siglo XVI en ningún caso mencionan un animal fantástico de semejantes características. Lo único que se le podría parecer es el glifo de lugar de Cinacantlán que aparece en el folio 15-v del Códice Mendocino (fig. 2). No obstante, las diferencias entre una y otra figura son evidentes. La pieza escultórica está trabajada con un esmero y delicadeza fuera de toda duda, revelando un dominio de los recursos plásticos por parte del artista. La del códice, en cambio, además de ser de pequeño tamaño es de muy pobre factura, con unos rasgos anatómicos descompensados y poco realistas.

Estamos ante un problema difícil de solucionar y cuya magnitud se acrecienta si tene-

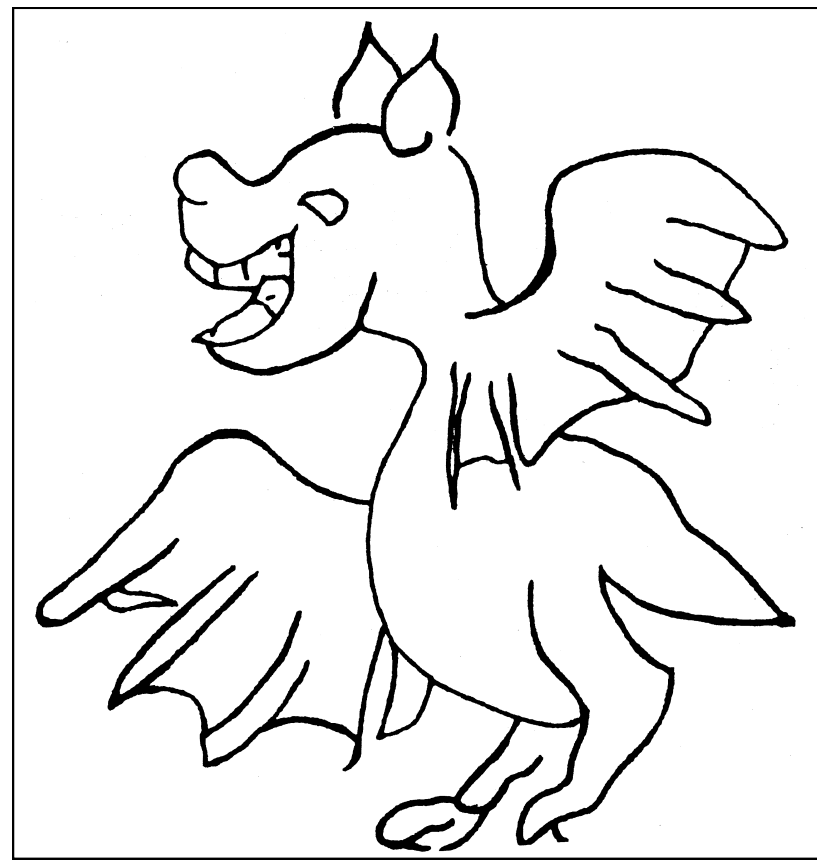

Fig. 2.-Glifo de lugar correspondiente a Cinacantlán. Códice Mendocino, fol. $15 \mathrm{v}$. mos en cuenta que un buen porcentaje de obras prehispánicas fue encontrado en contextos que poco tienen que ver con las premisas de un rescate arqueológico de probada cientificidad. En palabras de Litvak

al usar piezas con proveniencia defectuosa el historiador del arte construye sus conclusiones, en una proporción muy importante, sobre objetos que en lugar de ayudarlo a llegar a juicios correctos le estorban. ${ }^{3}$

3 Litvak King, Jaime: "El estudio del arte mesoamericano. Un punto de vista disidente". Cuadernos de Arquitectura Mesoamericana, n. ${ }^{\circ}$ 6, págs. 3-9. México, 1985, pág. 5. 
Evidentemente el asunto se complica si existe la posibilidad de que la pieza fuera realizada con posterioridad a la conquista: entraríamos de lleno en la discusión sobre la continuidad o disyunción de significados en la plástica prehispánica, e incluso en el de la pervivencia de creencias y concepciones ideológicas una vez que los parámetros de pensamiento sufren una transformación radical como consecuencia del proceso de aculturación que comienza con la llegada de los españoles, aspecto sobre el que se puede consultar una variada bibliografía ${ }^{4}$ y que se sale de las pretensiones de este trabajo.

Una vez mencionadas estas prevenciones, pretendemos en las líneas que siguen plantear un acercamiento más en profundidad a la pieza y sentar las bases para una discusión sobre su significado. Partimos, en este intento, del convencimiento de que toda obra de arte transciende sus peculiaridades morfológico-estilísticas, y se configura como elemento o eslabón lingüístico de un discurso perfectamente estructurado. Un discurso que no utiliza palabras sino que se articula a base de diseños plásticos, en este caso escultóricos, aunque como veremos más adelante la relación entre ambas esferas, la lingüística y la escultórica, es estrecha y permite establecer unos paralelismos fundamentales a la hora de desentrañar las claves de esta faceta de la plástica prehispánica.

Para empezar, relacionemos la obra en cuestión con otras más o menos cercanas. Como ya dijimos, se trata de la simbiosis de dos animales paradigmáticos en la plástica zoomorfa prehispánica, pero nunca representados de esta manera. Si nos remontamos en la tradición artística del Altiplano hasta Teotihuacán, encontraremos obras en las que es posible rastrear la asociación de águilas y felinos en distintas versiones. Tendríamos piezas escultóricas en las que, en los flancos de sus extremidades, se incorporan unos esquemas que tienden al escalonamiento y podrían ser reminiscencias muy transformadas de plumas o adornos a base de plumas. Tal es el caso del felino en ónice del British $\mathrm{Mu}-$

4 Entre otros, pueden consultarse al respecto los trabajos de Kubler, George: "Jaguars in the Valley of Mexico". The Cult of the Feline. A Conference on Pre-Columbian Iconography. Washington D.C., 1972, págs. 19-49; "Science and Humanism among Americanists". The Iconography of Middle American Sculpture. New York, 1973, págs. 163-167; "Renaissance and Disjunction”. Via, Journal of the Graduate School of Fine Arts. University of Pennsylvania, 1977, págs. 31-40; Willey, Gordon R.: "Mesoamerican Art and Iconography and the Integrity of the Mesoamerican Ideological System". The Iconography of Middle American Sculpture. New York, 1973, págs. 153-162; Townsend, Richard Fraser: State and Cosmos in the Art of Tenochtitlan. Washington D.C., 1979; López Austin, Alfredo: Los mitos del tlacuache. México, 1990. 
seum (fig. 3) o el de otro de alabastro encontrado en el Palacio de Quetzalpapalotl. El primero de ellos muestra en las plantas de las extremidades delanteras el glifo de Tláloc B o Tláloc-Jaguar, deidad a la que se relaciona fundamentalmente con la guerra y el sacrificio y, más lejanamente, con la tierra y el agua. ${ }^{5}$ En principio, esta identificación vendría corroborada por las dos oquedades en el lomo, lo que nos podría hacer pensar en recipientes para contener ofrendas, eventualmente sangre y corazones.

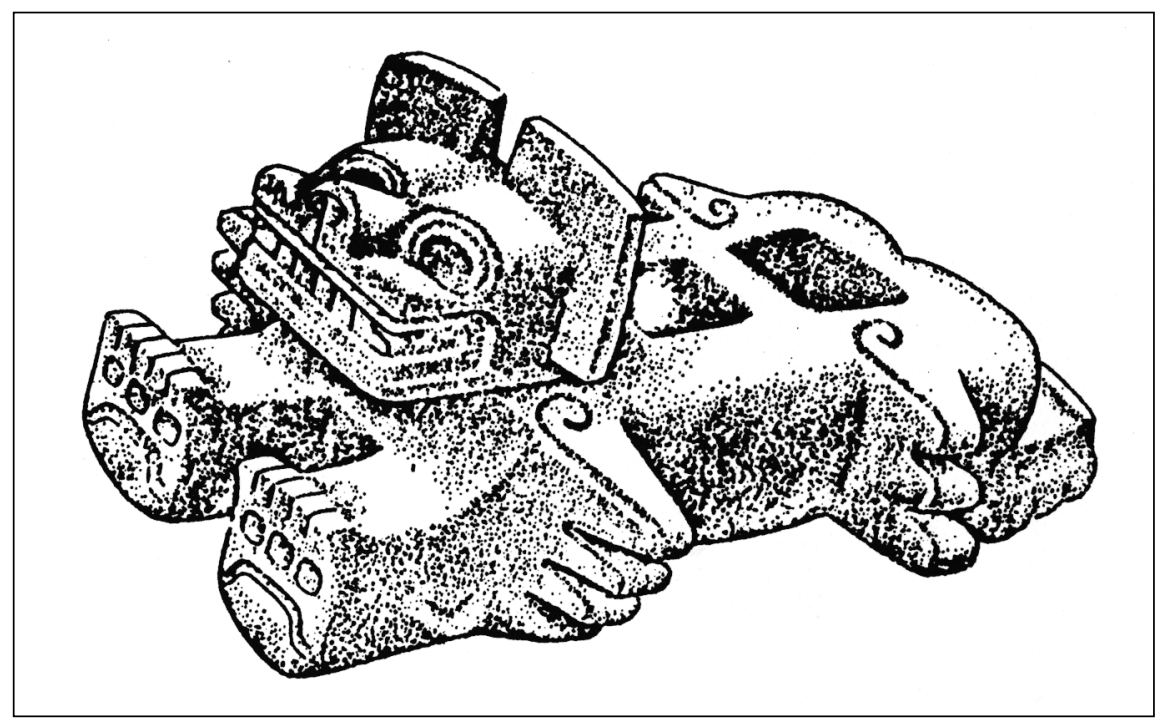

Fig. 3.-Felino teotihuacano en ónice. British Museum. Dibujo según Covarrubias.

En la pintura mural teotihuacana son numerosos los ejemplos de felinos con grandes tocados a base de largas plumas. Probablemente no correspondan en concreto a águilas, pero confieren al animal (que también puede estar en postura antropomorfa o ser un humano revestido con la piel de un felino) una categoría de rango superior. Sería el caso, por poner un ejemplo, de la procesión de felinos alternados con coyotes que aparecen en un mural del Patio Blanco de Atetelco (fig. 4). En este caso, el cuerpo y las extremidades del felino están además flanqueados por plumas más cortas; en la piel se dibujan esquemas reticulados, que al parecer se relacionan con

5 Winning, Hasso Von: La iconografía de Teotihuacán. México, 1987, vol. II, pág. 66. 
el agua y la fertilidad; ${ }^{6}$ bajo sus fauces aparece un dibujo trilobulado de carácter acuático, y, finalmente, en la cenefa que enmarca el mural se dibuja un corazón del que cuelgan cuatro gotas. Si a todo ello añadimos la lengua bífida del felino, nos acercaremos a los esquemas "felino-ave-serpiente" formulados por Kubler y que podemos encontrar en lugares como Monte Albán, Piedras Negras, Chalco o Chichén Itzá. ${ }^{7}$ En Teotihuacán se encuentran estos esquemas fundamentalmente en la cerámica anaranjada delgada (fig. 5). En algunos casos, como es el de una pintura del Palacio de Quetzalpapalotl (fig. 6), aparece el icono, pero la lengua bífida de serpiente ha sido sustituida por un corazón, lo que nos retrotrae a un complejo de significados que se basa en la estrecha relación entre fertilidad y sacrificio. ${ }^{8}$

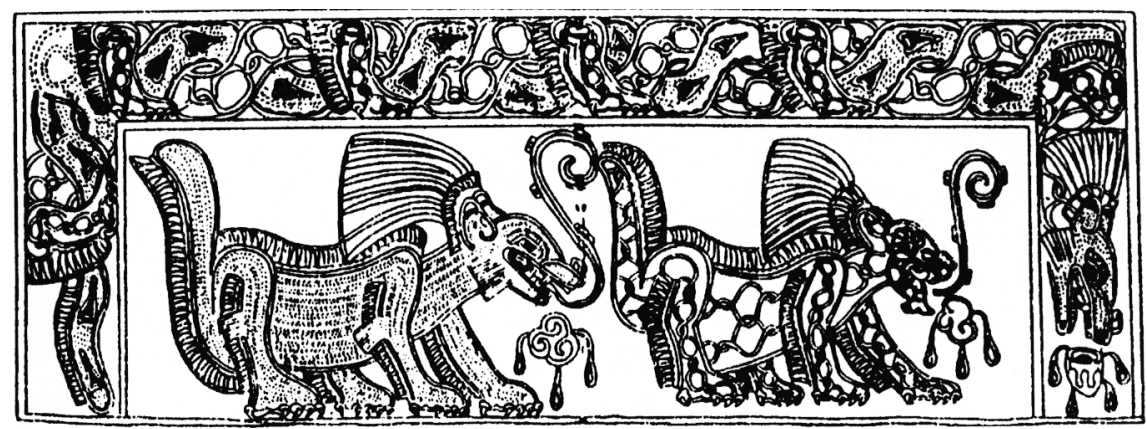

Fig. 4.-Pintura mural en el Patio Blanco de Atetelco, Teotihuacán. Dibujo según Sejournée.

Por otro lado, y buscando una continuidad a lo dicho acerca de Teotihuacán en tiempos posteriores, tenemos la alternancia de felinos y coyotes repetida una y otra vez en los relieves del Edificio B de Tula (fig. 7), en los que también aparecen figuras de águilas. Los elementos animales quedan separados aunque mantienen evidentes nexos entre sí, pero indudablemente los significados sufren una transformación. ${ }^{9}$ Predomina ya

6 Ibídem, vol. I, pág. 102.

7 Dicho icono, analizado por Kubler en su trabajo "Jaguars in the Valley of Mexico" (1972), ya había sido localizado en distintas ubicaciones por Spinden, Hebert J.: A Study of Maya Art: Its Subject Matter and Historical Development. Cambridge, 1913, pág. 251.

8 Díaz Balerdi, Ignacio: "La pintura teotihuacana: lenguaje unívoco o polivalencia significativa”. Anales del Instituto de Investigaciones Estéticas. México, 1986, pág. 14.

9 Kubler, G.: "Jaguars in the Valley...", pág. 38; Winning, H. V.: La iconografía de Teotihuacán, vol. I, pág. 99. 


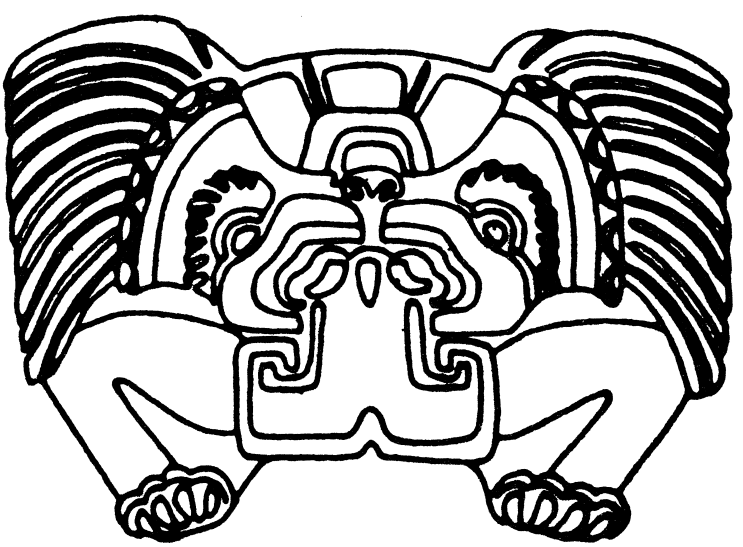

Fig. 5.-Dibujo de un relieve en una cerámica teotihuacana del tipo anaranjada delgada, según Sejournée.

el concepto guerrero, sobre todo a partir del comienzo del Postclásico, y ése va a ser, entre otros, uno de los principales aspectos en la iconografía de ambas figuras hasta la llegada de los españoles.

Ya en tiempos mexicas tenemos el océlotl-cuauhxicalli (fig. 8), en cuya cabeza aparece, como enmarcamiento a ambos lados, una especie de melena o barbas, en las cuales algunos autore ${ }^{10}$ han visto reminiscencias o sugerencias de plumas, quizá derivados de los primitivos iconos felino-ave-serpiente teotihuacanos. Entre los felinos de Mesoamérica estas

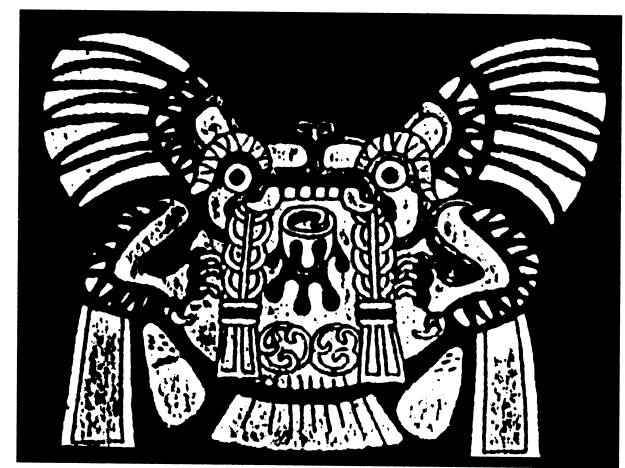

Fig. 6.-Pintura mural en el Palacio de Quetzalpapalotl, Teotihuacán. Dibujo según Miller.

10 Kubler, G.: "Jaguars in the Valley...”, pág. 41. 


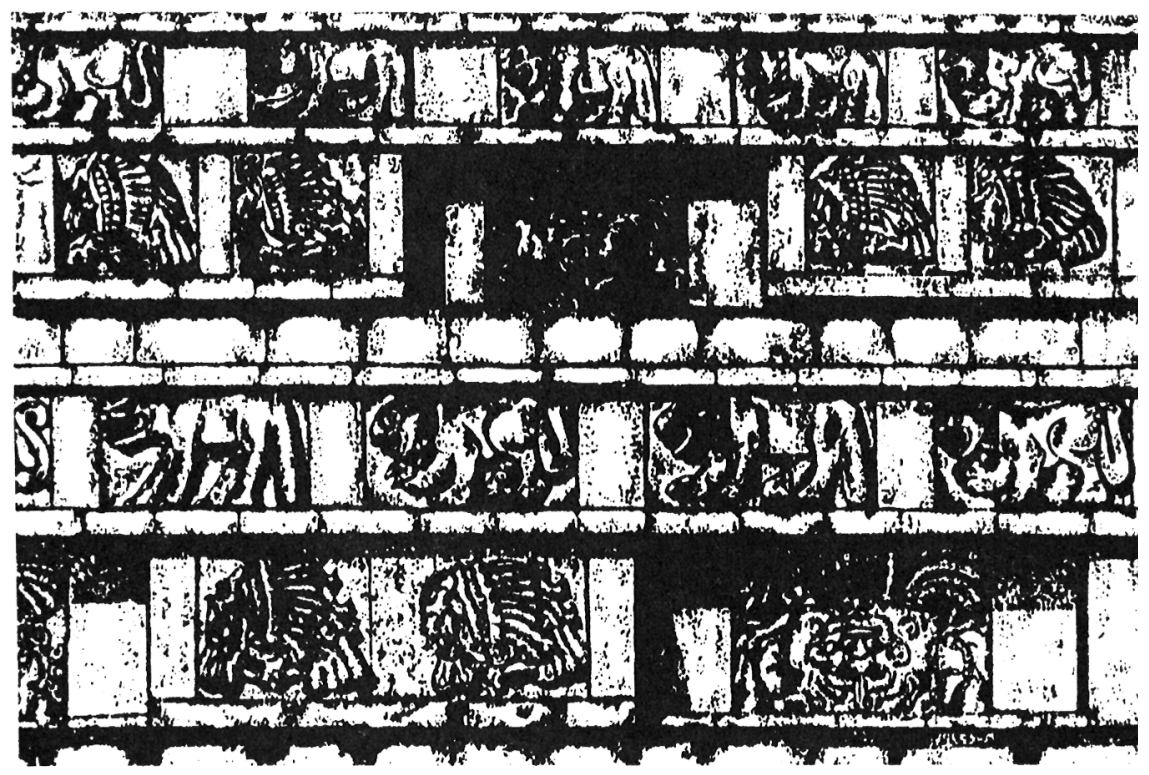

Fig. 7.-Relieves del Edificio B de Tula. Dibujo según Gendrop.

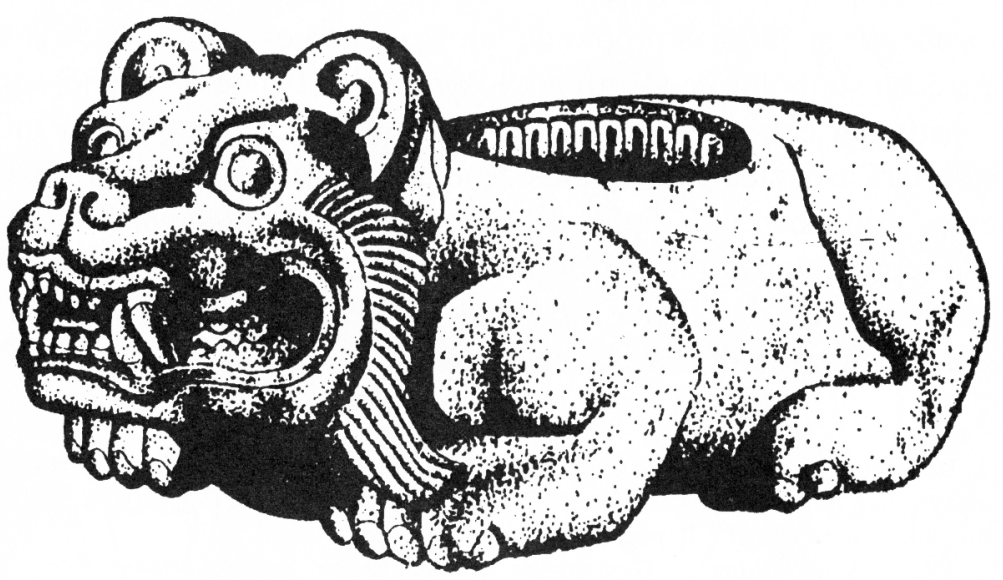

Fig. 8.—Océlotl-cuauhxicalli. MNA.Dibujo según Gendrop. 
barbas no son un rasgo común. Se asemejan más a la melena del león macho (animal desconocido en América) o a las barbas del tigre de Bengala. Tan sólo el lince, que sí es conocido por estas latitudes, las tiene, aunque hemos de puntualizar que dicho animal no es estrictamente hablando un felino. ${ }^{11}$ De todas formas, la mencionada pieza sí que incorpora plumas (o elementos vegetales con terminaciones achatadas y redondeadas) en la pared interior del recipiente trabajado en su lomo. En el fondo del mismo, dos figuras en relieve, probablemente Tezcatlipoca y Tlahuizcalpantecuhtli, se perforan las orejas con espinas penitenciales en un ritual relacionado con las órdenes militares de los guerreros águila y guerreros tigre. ${ }^{12}$ Nos movemos, por lo tanto, en unas coordenadas que nuevamente relacionan al felino con rituales de sacrificio.

En otros casos la relación entre ambos animales es más explícita. En Malinalco, en el interior del Monumento 1, tenemos águilas y felinos esculpidos a manera de tronos (fig. 9) en un contexto también relacionado con rituales de las órdenes militares antes citadas. Otro tanto ocurre con el huéhuetl de madera del propio Malinalco (fig. 10), que se estructura como una metáfora plástica del orden cósmico: la escena se halla presidida en el registro superior por el signo nahui ollin, con un guerrero-águila en actitud de danza ceremonial y un águila y un felino a los lados; en el inferior, correspondiente a las patas, otros dos felinos y un águila, tocados con el aztaxelli de plumas propio de tales personajes. ${ }^{13}$ En la escena también aparecen símbolos de sacrificio: los pámitl, o banderines, y los cuchillos de pedernal entre las plumas de las águilas. La parafernalia militar siempre estará asociada a las figuras de águilas y felinos. Recordemos que los mexica utilizaban una divisa de guerra, el chimaltetepontli, rodela en la que se representaban piernas de felino o de águila, y que se usaba con carácter ritual en la fiesta del mes Xócotl-Huetzi, en honor de Xiuhtecuhtli: ${ }^{14}$ eran parte de los adornos que ostentaban quienes habían

11 Un estudio sistemático sobre felinos y otros mamíferos en el continente americano se puede encontrar en Hall, Raymond: The Mammals of North America. New York, 1959, 2 vols. Para el caso concreto del lince, consúltese el t. II, pág. 969.

12 Véase Seler, Eduard: Gesammelte Abhandlungen zur Amerikanischen Sprach Atertunskunde. Berlin, 1904, vol. II, pág. 901. También Kubler, G.: "Jaguars in the Valley...”, pág. 41.

13 García Payón, José: "Los monumentos arqueológicos de Malinalco, Estado de México" Revista mexicana de Estudios Antropológicos, vol. 8, págs. 5-63. México, 1946, pág. 63.

14 Sahagún, Fray Bernardino de: Historia general de las cosas de la Nueva España. México, 1979, lib. II, cap. XXIX. 


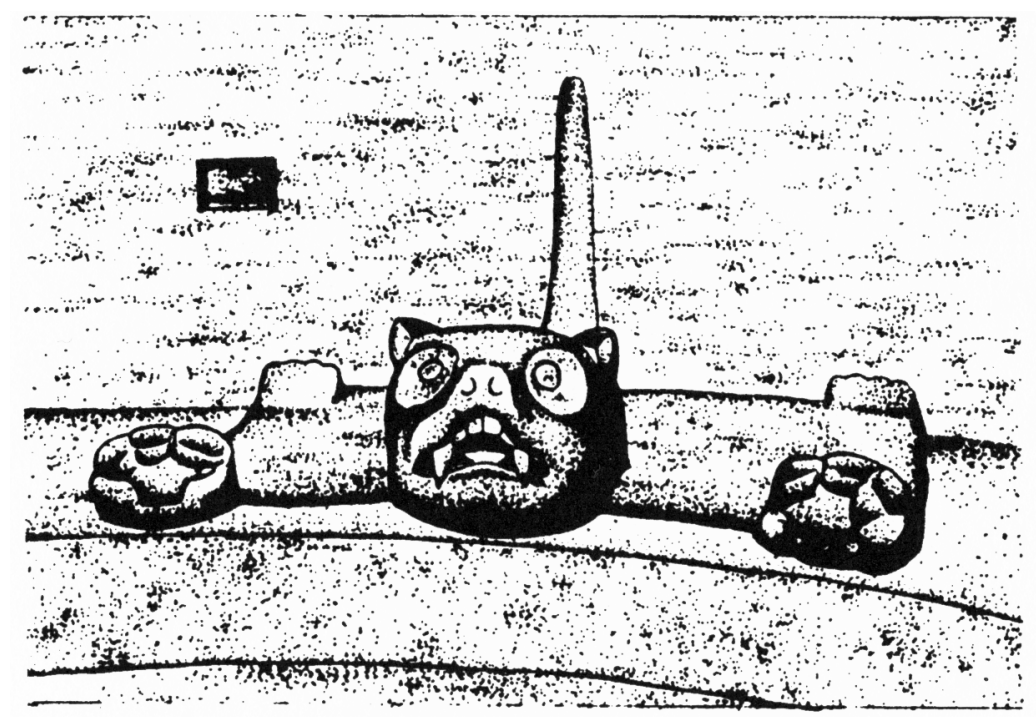

Fig. 9.-Interior del Monumento 1 de Malinalco. Dibujo según Gendrop.

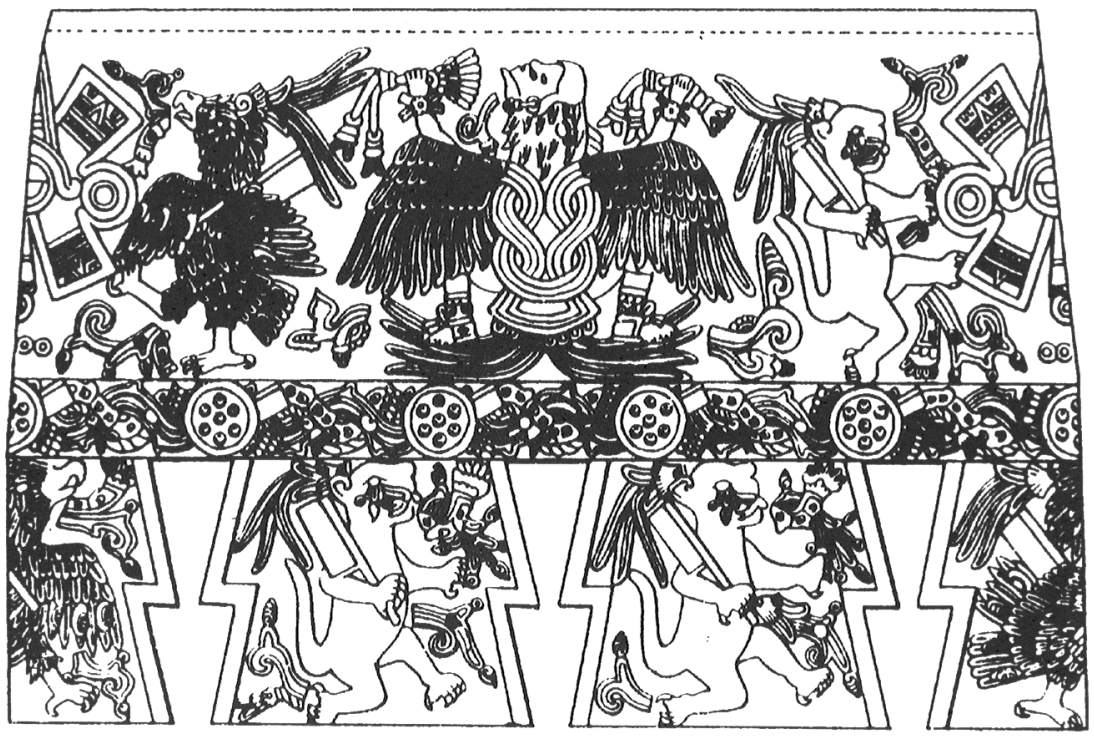

Fig. 10.-Desarrollo de los relieves del huéhuetl de madera procedente de Malinalco. Dibujo según Marquina. 
capturado prisioneros en el campo de batalla para ser sacrificados. Otro estandarte militar incorporaba la imagen de un águila descendiendo para apresar a un tigre..$^{15}$

También encontramos águilas y felinos asociados en algunos relieves de piedra (fig. 11). De las bocas de los animales, erguidos y situados frente a frente, parecen surgir vírgulas de la palabra que, unidas, forman el sig-

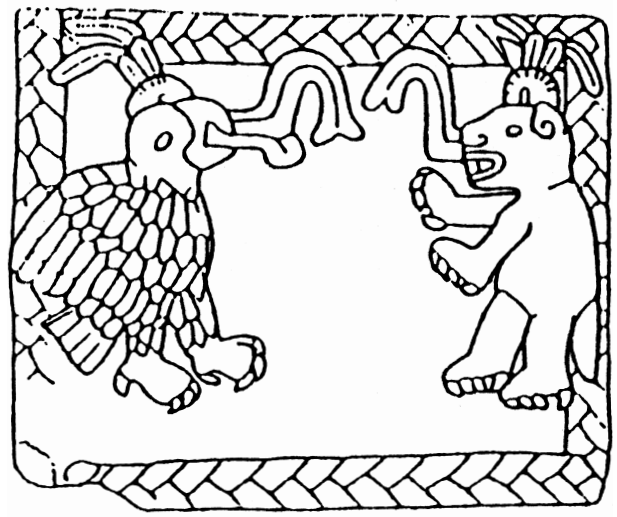

Fig. 11.-Relieve en piedra. MNA. Dibujo según Pasztory. no atl-tlachinolli, agua y fuego, sinónimo de guerra. El vocablo Atl se emplea para denominar en general cualquier tipo de líquido, pero el agua y la sangre eran los líquidos más importantes. Símbolos de la fertilidad y el sacrificio. Uno de los relieves está además en una de las caras de una piedra con otros relieves que incorporan un disco solar, un zacatapayolli, un glifo ácatl y un numeral: ${ }^{16}$ cosmogonía, orden, guerra y sacrificio se unen de manera indeleble. Realidad, ritual y ámbito de lo sagrado se estructuran como tres registros interdependientes en la cosmovisión mexica. En el fondo subyace la idea de que

la sociedad y la naturaleza descansan sobre la conservación de un orden universal, protegido por múltiples prohibiciones que aseguran la integridad de las instituciones, la regularidad de los fenómenos. ${ }^{17}$

En el mantenimiento de ese orden universal águilas y felinos van a desempeñar un destacado papel: los guerreros-águila y los guerreros-tigre serán los pilares más importantes de los cuerpos de élite de la milicia mexica. Su función será el mantenimiento del orden político (conquista, tributo, defensa ante agresiones, etc.) en la sociedad mexica. Pero ese orden político es tomado como un reflejo, a escala cotidiana, del orden cósmico. O lo

15 Clavijero, Francisco Javier: Historia Antigua de México. México, 1982, lib. VII, 24.

16 Gutiérrez Solana, Nelly: Objetos ceremoniales en piedra de la cultura mexica. México, 1983, pág. 130 .

17 Caillois, Roger: El hombre y lo sagrado. México, 1984, pág. 147. 
que es lo mismo: el orden político se mantiene para asegurar la permanencia e inalterabilidad del orden cósmico. No es casual que los mexica se considerasen a sí mismos el pueblo del sol, los garantes de que el universo prosiguiera su curso sin alteraciones.

Ya hemos mencionado cómo en el huéhuetl de Malinalco los felinos y las águilas llevaban banderines de sacrificio. También los encontramos así en la lámina 11 de los códices Borbónico y Tonalámatl de Aubin (figs. 12 y 13), láminas correspondientes al signo calendárico Ce Ozomatli, "1 mono", y cuyo numen es Pahtécatl, uno de los dioses de la fertilidad que

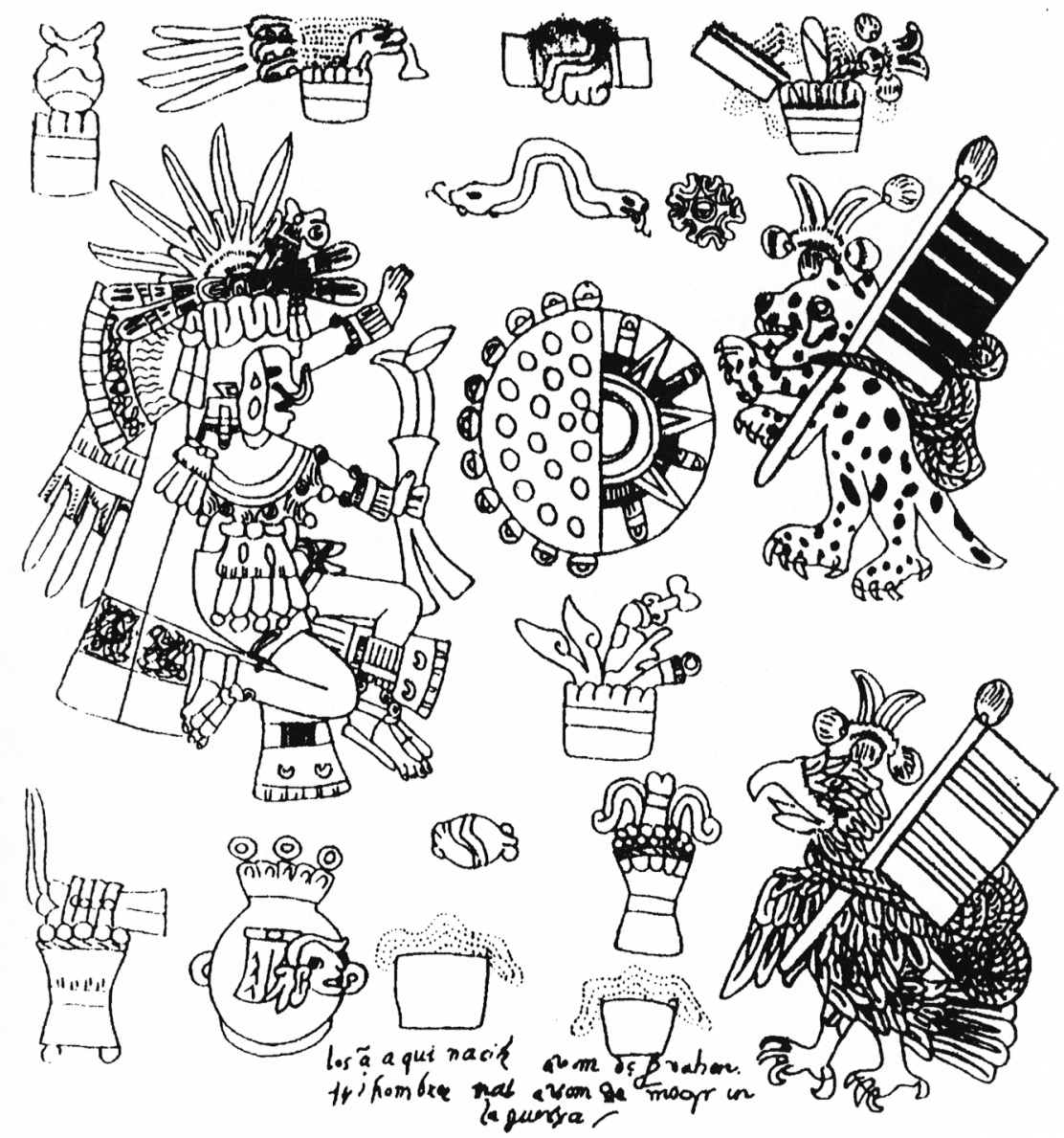

Fig. 12._Lámina 11 del Códice Borbónico. Dibujo de Mercedes del Corral. 


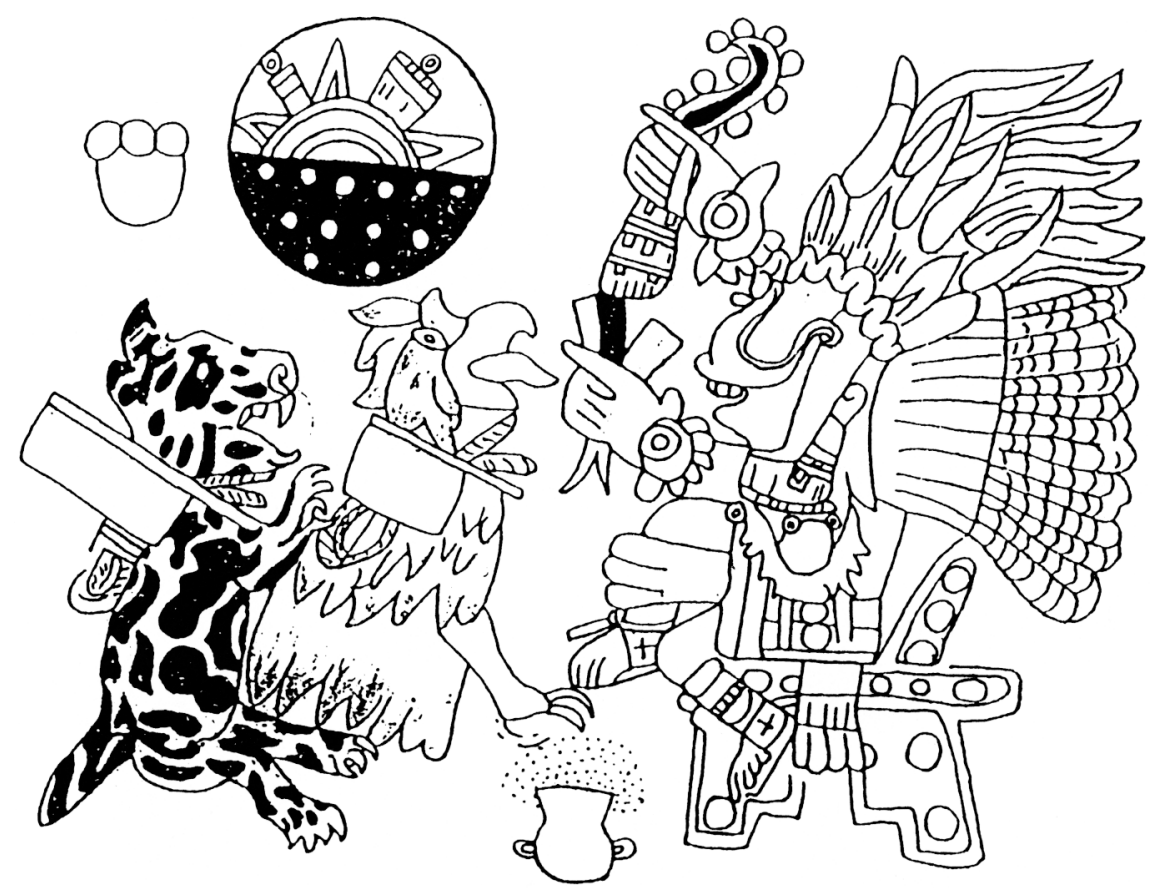

Fig. 13._Lámina 11 del Tonalámatl de Aubin. Dibujo de Mercedes del Corral.

personificaba la planta del maguey y su derivado, el pulque; recordemos que el pulque mismo estaba personificado en una diosa, Mayahuel, relacionada estrechamente con Chalchiuhtlicue y con Xochiquetzal, diosas de la fertilidad. ${ }^{18}$ En la lámina del Borbónico aparecen varios elementos asociados (serpiente bicéfala, chalchihuite, corazón, etc.), pero dos de ellos se repiten en la del Tonalámatl de Aubin: el círculo del día y la noche y las vasijas de pulque. Además, en el primero hay una leyenda en español que dice que los nacidos en este signo habían de morir en la guerra. Sahagún ${ }^{19}$ también informa de que era un signo de mala fortuna, aunque sin mencionar la guerra.

Para buscar el hilo conductor que haga lógico todo este entramado debemos remontarnos a los orígenes más remotos, al momento de la creación del quinto sol que, evidentemente, constituye un acto sacrificial:

18 Nicholson, Henry B.: "Major Sculpture in Pre-Hispanic Central Mexico". Handbook of Middle American Indians, vol. 10, págs. 92-134. Austin, 1971, pág. 120.

19 Sahagún: F. B. de: Historia general..., lib. IV, cap. X. 
Nanahuatzin y Tecuciztécatl, los dioses protagonistas, se arrojan al fuego y se dice que se habían arrojado un águila y un tigre, ${ }^{20}$ por lo que a los hombres diestros en la guerra se les llamará en adelante quauhtlocélotl. De ahí se derivarán una serie de frases metafóricas y difrasismos en torno al concepto de la valentía recogidos por Sahagún, ${ }^{21}$ entre los que citaremos dos: Estrado de tigre, estrado de águila, para aludir a los guerreros invencibles que defienden la ciudad, y Con águilas, con tigres, para referirse a los esfuerzos necesarios para la consecución de objetivos elevados. Quauhtli (águila) y océlotl (tigre) además de tomarse como denominación de los guerreros valientes se deben entender también como una alusión al cielo diurno y al nocturno. ${ }^{22}$ Volvemos sobre un tema recurrente: águilas y felinos conforman un binomio antagónico, pero a su vez complementario, en ese proceso de bipolaridad consustancial al pensamiento mesoamericano. Y esa bipolaridad manifestada en el tiempo primordial de los orígenes, del principio, en el tiempo del mito, también tendrá su reflejo en el ritual, en el arte y en la vida cotidiana.

Aguilas y felinos con banderines de sacrificio pueden perfectamente hacer alusión al sacrificio de Nanahuatzin y Tecuciztécatl y a su transformación en el sol y la luna. Las sogas que aparecen sujetando dichos banderines a los cuerpos de los animales en los códices aludían a que el asunto era de gran responsabilidad. ${ }^{23} \mathrm{El}$ signo atl-tlachinolli introduce el factor agua en sus dos acepciones: sacrificial y de fertilidad. Y también alude a los orígenes, pues según $\mathrm{Serna}^{24}$ el mencionado sacrificio para la creación del quinto sol fue per ignem et aqua, por fuego y agua. Aguilas, felinos, sacrificio, guerra, agua y fuego articulan un discurso polivalente plasmado en tres registros: el real, el ritual y el mítico.

Este estado de cosas, esta parcela de la cosmovisión mexica va a encontrar su reflejo en la literatura. En la Colección de cantares mexicanos, (fol. 18-r) un poema dice así: ${ }^{25}$

20 Ibídem, lib. VII, cap. II.

21 Ibídem, lib. VI, cap. XLIII.

22 Krickeberg, Walter: Mitos y leyendas de los aztecas, incas, mayas y muiscas. México, 1980, pág. 213.

23 Sahagún, F. B. de: Historia general..., lib. VI, cap. XLIII.

24 Serna, Jacinto de la: "Tratado de las supersticiones, idolatrías, hechicerías y otras costumbres de las razas aborígenes de México". Tratado de las idolatrías, supersticiones, dioses, ritos, hechicerías y otras costumbres gentílicas de las razas aborígenes de México, vol.I, págs. 40-370. México, 1953, pág. 197.

25 Garibay, Angel M. ${ }^{\text {a: }}$ La literatura de los aztecas. México, 1982, pág. 58. 


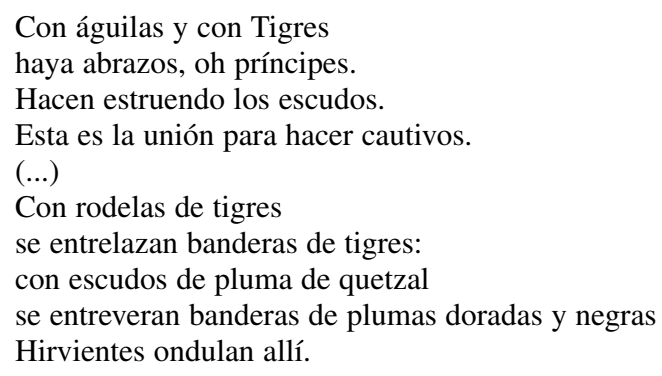

Se habla de la guerra y de sus protagonistas. De una guerra recurrente, cíclica: ${ }^{26}$

Cual nenúfar al viento gira el escudo, cual humo el polvo sube, el silbo de las manos repercute, aquí en México Tenochtitlan.

En la casa de los escudos, en la casa de las batallas: se extiende el estrado del Aguila, es el sitio del solio del Tigre: ellos llevan el peso de la guerra. Se toca la flauta para el combate: son las flores del Escudo que resplandece [el sol], ¡Nunca, nunca por cierto ha de acabar! (Cantares mexicanos, fol. 21-r.)

Y en la misma colección: ${ }^{27}$

Desde donde se posan las águilas, desde donde se yerguen los tigres, el Sol es invocado.

Como un escudo que baja, así se va poniendo el Sol.

En México está cayendo la noche, la guerra merodea por todas partes. ¡oh Dador de la vida! se acerca la guerra.

26 Ibídem.

27 León-Portilla, Miguel: Los antiguos mexicanos. México, 1977, págs. 78-79. 


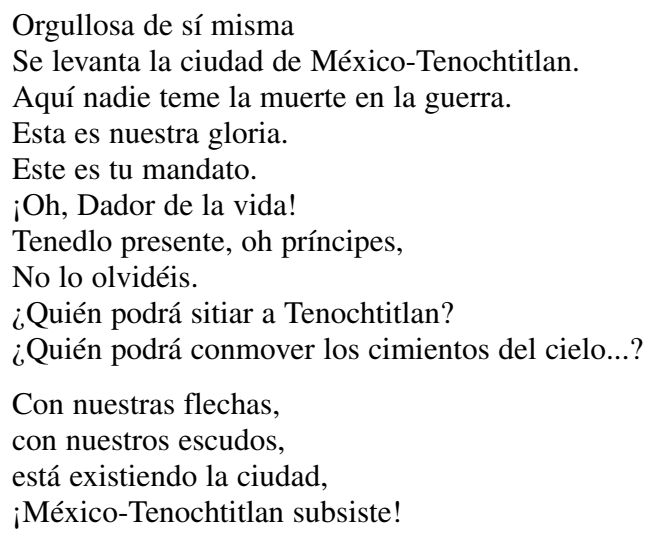

Aquí se resume de algún modo lo que hemos estado analizando hasta el momento. De manera metafórica el poema nos describe cuáles son en última instancia las bases en las que se fundamenta toda una concepción cosmogónica. El esplendor del sol —el orden del universo- se asocia a las águilas y a los tigres. Pero también se asocia a ellos el esplendor de la ciudad, el poder de México-Tenochtitlan, la orgullosa de sí misma, la que constituye los cimientos del cielo. Recordemos que en la primera página del Códice Mendocino, donde se representa la fundación de la ciudad y donde aparecen los señores que eligen a Tenoch como gobernante, dos de ellos llevan sendas banderas en el triángulo superior: Acacitli (tigre) y Quapan (águila).

Indudablemente, tanto felinos como águilas, tomados de uno en uno, se asocian a otra serie de significados en los que aquí no voy a profundizar. No porque carezcan de importancia, sino porque de lo que se trata es de intentar averiguar el significado de una escultura en la que ambos animales aparecen en simbiosis. Como hemos podido ver a lo largo de las páginas anteriores, tal simbiosis nunca es mencionada en lo referente a divinidades u obras de arte. Aguilas y felinos aparecen en asociación, tanto literaria como plástica, pero cada uno de ellos acusando rasgos específicos que los identifican y personalizan. Debemos, por tanto, partir de la consideración no ya de dos animales sino de la unidad lograda mediante la yuxtaposición de ambos. En este sentido, habría que inscribirlos en una estructura discursiva plástica y plena de significados, más cercana a los modos de hacer propios de la poesía que a los de la prosa. ${ }^{28}$

28 Pasztory, E.: Aztec Art, págs. 82-83. 
El arte mexica en su vertiente lingüística, así como los evidentes nexos entre las formas de expresión artística y el náhuatl, la lengua de los mexica, es un tema de capital importancia y del que diversos autores se han ocupado. Soustelle ${ }^{29}$ piensa que el náhuatl

puede ser caracterizado como un instrumento de transmisión de asociaciones tradicionales, de bloques, si se quiere, de enjambres de imágenes.

León-Portilla ${ }^{30}$ especifica más en lo referente al lenguaje y afirma que

el náhuatl, así como el griego y el alemán, son lenguas que no oponen resistencia a la formación de largos compuestos a base de la yuxtaposición de varios radicales, de prefijos, sufijos e infijos, para expresar así una compleja relación conceptual con una sola palabra, que llega a ser con frecuencia verdadero prodigio de ingeniería lingüística.

Por su parte, Alcina ${ }^{31}$ propone unas bases metodológicas para analizar el arte mexica como si de un lenguaje se tratara, y en el cual no sólo cabe distinguir categorías sustantivas, verbales o adjetivas, sino también metáforas, tropos y difrasismos.

A partir de lo apuntado por León-Portilla, podríamos establecer incluso un paralelismo entre las constantes morfológicas que se detectan en las esculturas mexicas y el mencionado tipo de estructura lingüística. La mayoría de las esculturas se articulan en torno a un núcleo central sobre el que se desarrollan casi en relieve una serie de elementos, los cuales identifican la pieza, le confieren especificidad y la nutren en mayor o menor cuantía de signos que enriquecen su significado último. Es en realidad el mismo proceso que sigue el idioma, a base de un radical acompañado de una serie de afijos que lo conforman y matizan.

En el caso de la pieza que nos ocupa estaríamos ante un ejemplo de estas características. Las superficies del bloque de piedra se trabajan a base de modelados que dan como resultado una simbiosis fantástica. Los dos animales que lo forman son muy importantes, emblemáticos. Juntos aparecen en varias obras y encarnan un aspecto fundamental del principio de bipolaridad consustancial al pensamiento mesoamericano. Forman una oposición conceptual parecida a la que se establece entre el disco solar y el monstruo de la tierra, hacen referencia a las órdenes militares de guerre-

29 Soustelle, J.: La pensée cosmogonique, pág. 9.

30 León-Portilla, Miguel: La filosofía náhuatl. México, 1979, pág. 56.

31 Alcina Franch, José: "El arte mexica como lenguaje". Fragmentos, n. ${ }^{\circ}$ 7. Madrid, 1986, págs. 18-37. 
ros-águila y guerreros-felino, y cada uno de ellos aporta sus peculiares derivaciones de significados: el águila es un ser diurno y habita el cielo, mientras que el felino es nocturno y se relaciona con el inframundo, derivando su aparición como emblema plástico de la metáfora verbal que hace referencia a los soldados valientes, quienes, en última instancia, son los encargados de alimentar al sol y a la tierra..$^{32}$

En mi opinión, la escultura en cuestión es un ejemplo de escultura ideográfica que representa un principio de oposición mediante el cual se articula una metáfora conceptual específica, relacionada con todos los parámetros de orden militar que venimos analizando hasta ahora y que podríamos resumir en cuatro palabras: guerra, sacrificio, fertilidad y orden. Su plasmación como concepto lingüístico no es otra que el vocablo quauhtlocélotl: "hombre diestro en la guerra".$^{33}$ Hasta ahora, quauhtli, águila, y océlotl, jaguar, aparecían separados. De su conjunción se derivaba una serie de implicaciones ideológicas, pero era una conjunción a base de dos elementos perfectamente diferenciados. Aquí, no. Aquí los elementos se ensamblan, pierden algo de su propia mismidad, valga la expresión (no queda el cuerpo del felino ni la cabeza del águila), pero su identificación queda fuera de duda al incorporar elementos claves: la cabeza del felino y el cuerpo emplumado del águila resumen y aglutinan de manera referencial las características y poderes más específicos de ambos animales, en un ejercicio de expresión plástica sutilmente definida por Clavijero: ${ }^{34}$

representaban las cosas materiales con su propia figura y, para abreviar, con una parte de ella bastante (sic) a darla a conocer a los inteligentes.

Quauhtli, águila, y océlotl, felino, jaguar en su manifestación más paradigmática. Quauhtlocélotl, como resultado final. Simbiosis en la que también se establece un orden ${ }^{35}$ que no sólo es de nomenclatura. Primero águila y después felino, pues no entraron al mismo tiempo los dos en la hoguera sacrificial de Teotihuacán para la creación del quinto sol: el águila, que lo hizo en primer lugar, saldría convertida en el sol y el felino en la luna. El principio dual o de bipolaridad encontraba una de sus plasmaciones paradigmáticas que, en adelante, teñiría con su impronta cualquiera de las esferas conceptuales del pensamiento mexica.

32 Pasztory, E.: Aztec Art, pág. 82.

33 Sahagún, F. B. de: Historia general..., lib. VII, cap. II.

34 Clavijero, F. J.: Historia Antigua..., lib. VII, 49.

35 Díaz Balerdi, Ignacio: Los felinos en la escultura azteca. Tesis doctoral. Universidad Complutense. Madrid, 1990, pág. 294. 